IRA-International Journal of Management \& Social Sciences

ISSN 2455-2267; Vol.14, Issue 03 (March, 2019)

Pg. no. 60-67.

Institute of Research Advances

http://research-advances.org/index.php/RAJMSS

\title{
Information Scientist and Some Similar Professionals: Their Role as a Caretaker of Security Vis-à-Vis IT Management-An Analysis
}

\author{
P. K. Paul ${ }^{1 \#}$, A. Bhuimali ${ }^{2}$, Krishna Raj ${ }^{3}, \&$ P. S. Aithal ${ }^{4}$ \\ ${ }^{1}$ Executive Director, MCIS, Raiganj University, West Bengal, India \\ ${ }^{2}$ Vice Chancellor, Raiganj University, Raiganj, West Bengal, India \\ ${ }^{3} \mathrm{CESP}$, Institute of Social and Economic Change (ISEC), Bengaluru, KN, India \\ ${ }^{4}$ Vice Chancellor, Srinivas University, Karnataka, India
}

\# corresponding author

Type of Work: Peer Reviewed.

DOl: http://dx.doi.org/10.21013/jmss.v14.n3.p1

\section{How to cite this paper:}

Paul, P.K., Bhuimali, A., Raj, K., Aithal, P.S. (2019). Information Scientist and some similar professionals: Their Role as a Caretaker of Security Vis-à-Vis IT Management-An Analysis. IRA-International Journal of Management \& Social Sciences (ISSN 2455-2267), 14(3), 60-67. doi:http://dx.doi.org/10.21013/jmss.v14.n3.p1

(C) Institute of Research Advances.

\section{(cc) EY-NC}

This work is licensed under a Creative Commons Attribution-Non Commercial 4.0 International License subject to a proper citation to the publication source of the work.

Disclaimer: The scholarly papers as reviewed and published by the Institute of Research Advances (IRA) are the views and opinions of their respective authors and are not the views or opinions of the IRA. The IRA disclaims of any harm or loss caused due to the published content to any party.

Institute of Research Advances is an institutional publisher member of Publishers International Linking Association Inc. (PILA-CrossRef), USA. The institute is an institutional signatory to the Budapest Open Access Initiative, Hungary advocating the open access of scientific and scholarly knowledge. The Institute is a registered content provider under Open Access Initiative Protocol for Metadata Harvesting (OAI-PMH).

The journal is indexed \& included in WorldCat Discovery Service (USA), CrossRef Metadata Search (USA), WorldCat (USA), OCLC (USA), Open J-Gate (India), EZB (Germany) Scilit (Switzerland), Airiti (China), Bielefeld Academic Search Engine (BASE) of Bielefeld University, Germany, PKP Index of Simon Fraser University, Canada. 


\begin{abstract}
Information is the most important and powerful term in today's age. Information is needed in almost all the areas and sectors, and there are many practitioners who manage the information and similar contents. Among them, few important are the Chief Information Officer, Information Manager, Information Analyst domains and specific information managerial areas such as Archivist, Librarian, Documentation Officer and so on. Information Scientist, however, performs a different role and duties and responsibilities for the information management with technological solutions and also technology management depending upon need. Creating information systems with proper planning and management are the important task of an Information Scientist. Though there are many misconceptions about these professionals. This paper talks about such professionals and relationship with the Information Scientist.
\end{abstract}

Keywords- Information Scientist, Computer Scientist, Information Infrastructure, Computing, Information, Information Age, Human-Computer Interaction, Information Man Interaction.

\title{
Introduction-
}

Information Scientist is the professionals who deal with the technological and managerial side of the information for the industries, academic and research units. Information Scientist is mainly dedicated to the whole information infrastructure building with the use of technologies such as computing and information technologies. Importantly Information Scientist plays an important and lead role for building and creating information systems not only with the proper technologies and management but also with the use of other psychological tools, and methods especially the cognitive science. Information Scientists are mainly responsible for technological implementation, academic and professional improvement with solid and healthy information designing. Information Architecture and its proper principles applications and utilizations are treated as most valuable and important.

\section{Objectives and Agendas-}

The core aim and agenda of this paper include but not limited to the-

- To know about the Information Scientist and its basic features and characteristics.

- To learn about the basic role and responsibilities of Information Scientist in a conceptual manner.

- To learn about the recent and current jobs and activities of Information Scientist.

- To know about the similar profession and their role compares to Information Scientist.

- To know about the some of the allied Information Scientist such as Chief Information Officer, Information Managers, Chief Experience Officer, Librarian, Information Analyst, Software Analyst, Network Administrator and so on.

\section{Information Scientist: Basics-}

Information Scientists is mainly responsible for Information in addition to Technological solutions and services. Information Scientists dedicated to proper activities Information Management and for that, they are basically collect, select, organize, and disseminate information and contents [05], [07], [15]. Information Scientist also works as a system and network administrator but 'they are not only deal the technological solutions with database management, software management, web technology, network management moreover they deal the properties and behaviour of information (Refer Fig: 1). Moreover they needs for proper information infrastructure building [03], [04], [19]. Earlier Information Scientist only considered as sophisticated IT and Technology focused Information Centric professionals and helpful to all type of organization including profit making but today they are kind of Technology professionals with the focus on Information and Content [01], [02], [17]. 


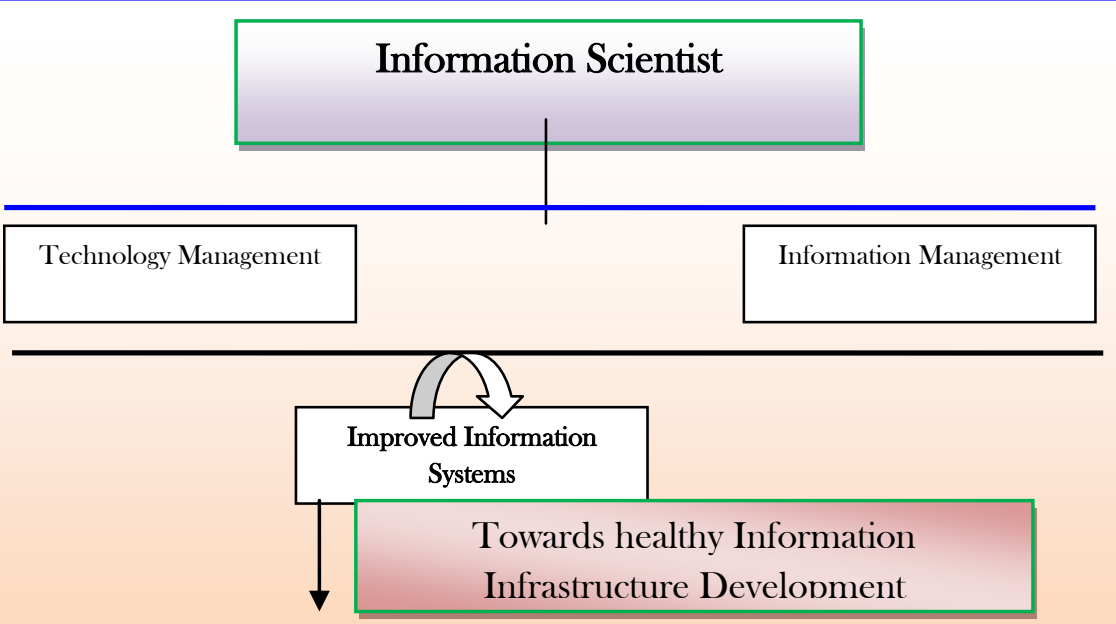

Fig: 1-Depicted the Information Scientist and allied Professionals role for solid Development of Society powered by Technologies.

\section{Information Scientist and similar Professions-}

The term scientist conveys that Information Scientist is accountable for solid along with healthy scientific works and investigation of the information [06], [09], [16]. Information Scientist moreover also investigates the properties as well as the behaviour of information and organizes by using various kinds of tools and technologies. Information scientist is also measured as an investigator in the field of information science \& Technology (IST). But there are many professionals who are also engaged in a large amount of information and technological aspects which include as follows (also refer Fig: 2) -

\section{Chief Information Officer (CIO)_-}

The designation of Chief Information Officer (CIO) is another designation which is very much close to the post of Information Scientist. The Chief Information Officer (CIO) normally deals with technology management and overall technology governance [08], [10], [18]. They have to implement and use several technologies and tools including the systems, applications, and programs in the context of corporate settings [11], [20]. 


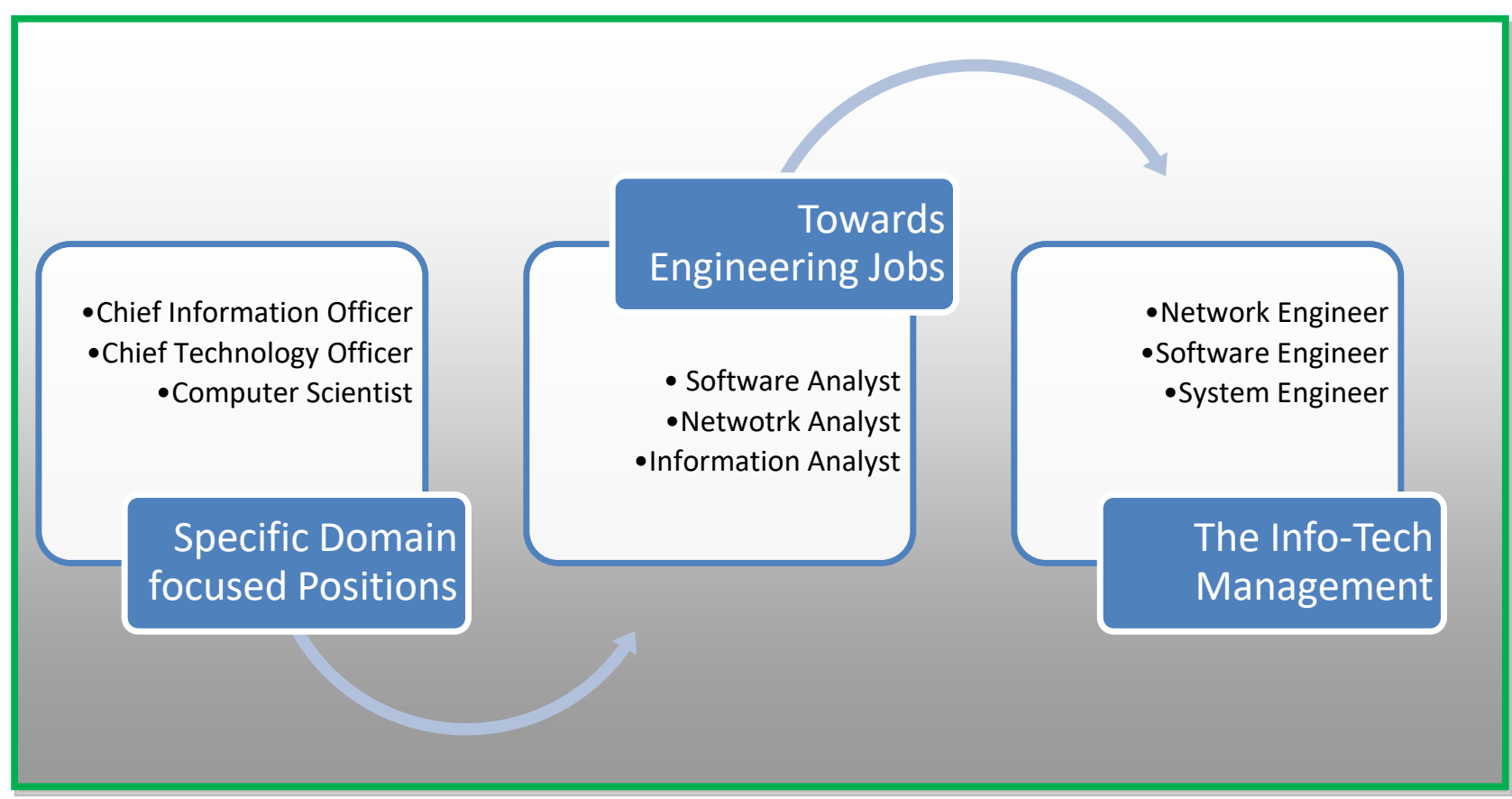

Fig: 2-Depicted the professionals and engineers who are very much close with the Information Scientist.

Importantly the Chief Information Officer (CIO) has also taken the responsibilities of public relation management and overall corporate governance [12], [21], [22]. Chief Information Officer (CIO) is dedicated to the casual monitoring of technology and systems for better and healthy information management. The corporate skills and similar attitude are very much important and common in Chief Information Officer (CIO). The managerial aspects are also required for solid and healthy information management and side by side technology management. The position of Chief Information Officer (CIO) is most apex and in the line of Chief Executive Officer, Chief Operation Officer, Chief Financial Officer etc. the initial planning of the information and related systems including the information technology are the key role for the better and healthy informatics practice in an organization or company. Practically the Chief Information Officer (CIO) has to do the task as Business Analyst and Information Analyst in many contexts [13], [14], [19]. The policy-making, and decision making related to information and communication have to deal but today's Chief Information Officer (CIO).

Moreover, the creation of new systems and managing the same is also an important job and task of the Chief Information Officer (CIO). Chief Information Officer also needs the solid and healthy skills of the business and corporate houses and integrating the IT and Computing skills for better and healthy output. The sustainability of the IT including the environmental informatics practice and information solutions are also the valuable task of the modern CIOs [15], [23], [24]. The identification and development of the capabilities of the new tools are also the most important task of the Chief Information Officer (CIO). The most important task and jobs of the Chief Information Officer (CIO) are listed in Table: 1.

Table: 1- The Domain That Should Know a Chief Information Officer (CIO)

\begin{tabular}{|l|l|}
\hline \multicolumn{2}{|c|}{ Chief Information Officer: Some Key Task and Areas } \\
\hline Business Analysis & IT Management \\
\hline Enterprise Resource Planning & Information Systems Designing \\
\hline IT Policy and Development & Corporate Skills \\
\hline CRM & Legacy Modernization \\
\hline Decision Support Systems & Knowledge Management \\
\hline Management Information Systems & Systems Re Engineering \\
\hline E-Governance & IT Cycling \\
\hline
\end{tabular}




\section{Computer Scientist-}

The Computer Scientist position is similar to the Information Scientist in many contexts [16], [17], [25]. The Computer Scientist is purely engaged in the theoretical foundations of the computing and which include the following-

- Practicing and research activities on the data structure and development and designing of the systems related to the software and applications.

- Engagement in the areas of information theories from a working perspective to research perspective.

- The Computer Scientist normally works on the compare complexity, VLSI, numeral analysis, computer graphics, database theory, programming languages etc [17], [26], [27].

- Developing mathematical modelling and creation of computer-based systems are the major task of the Computer Scientist.

In exceptional cases, the Computer Scientist may also engage in practical and applications related to computing and software engineering. Information Technology and allied areas also become an important task of the Computer Scientist. The recent past the job related to the Information Technology project management has also become part of the Computer Scientist. Designing and development of new approaches in computing fields are also important and valuable for the Computer Scientist [16], [19].

\section{Information Analyst -}

One of the important and allied professions of Information Scientist is Information Analyst in some contexts. However, Information Analyst needs to deal with much traditional analysis and important operations related to information analysis only. The Information Scientist also needs to do the Information Analysis. An Information Analyst is basically responsible for the following aspects and assignments-

- Conducting Analysis of Information and Data.

- Designing and Management of the Information Systems and Analysis related affairs.

- Analysis and Tracking the Data depending upon needs.

Normally Information Analyst collects, selects, organize and provides data and information. Information Analyst basically helps in the process of information management and better information governance. Information Analyst may also deal with the analysis of the following technologies depending upon the need for better and solid information analysis practice (See Table: 2 ).

Table: 2- Depicted the possible technological analysis areas of an Information Analyst.

\begin{tabular}{|l|l|}
\hline \multicolumn{2}{|c|}{ Information Analysis and Possible Technological Affairs } \\
\hline Networking Technologies & Web Technologies \\
\hline Computing Technologies & HCI Systems \\
\hline Database Technologies & Information Systems Technologies \\
\hline Multimedia Technologies & Data Management Systems \\
\hline
\end{tabular}

\section{Software Engineer-}

Software Engineer is another position which also many ways dedicated to the software related affairs or an organization [17], [26], [27]. Software and system engineering are the key tasks of the Software Engineer. Information Scientist normally carries the task of the information systems and management and including the communication management apart from technology management. However, a Software Engineer normally applies the rules and principles of the Software Engineer regarding the designing, development, and testing as well as evaluation of software and systems as well. Previously the Software Engineer is known for software programmes 
and computer programmes and even software developer. Solving software related problems and cycling of software systems life cycles are the key task of Software Engineer. Information Scientist normally recruited in the academic and industrial settings and whereas the Software Engineer engages in the industries mainly. Software Engineers are also working for the software testing, analysis, software development, software quality management, software cycling management and so on [17], [26], [27].

Software Engineer may also work in the off-campus basis whereas Information Scientist normally works at the campus or in the organization. Software Engineer may also get a designation as Research Software Engineer compares to Information Scientist normally hold the research jobs as well. The structured programming, object orientation, and data modelling are the key task of a Software Engineer and they may also help in the activities of information management by designing programs.

\section{System Analyst-}

System Analyst is an information professional who is engaged in the process of the information systems related activities ranging from the analyzing, designing and implementing systems in an organization or company. The System Analyst basically analyzes the systems whereas Information Analyst mostly responsible for analyzing information and data. System Analyst evaluated the justification as well as the suitability of IT with the clientele and including the vendors of the software [16], [28].

The System Analyst involves in the designing segment of the software and systems too and always engages in the improvement of the analyzing and designing of the existing systems. Managing IT and Computing Systems are the indirect work of a System Analyst. The key task of a System Analyst is depicted in Table: 3.

Table: 3- Depicted the possible key task and areas of a System Analyst.

\begin{tabular}{|c|c|}
\hline Investigating Systems & Systems Analysis \\
\hline Systems Designing and Programming & Technical Reviews of software and hardware \\
\hline Operation Management and Systems Evaluation & $\begin{array}{l}\text { Develop healthy manual information tools into } \\
\text { automated systems }\end{array}$ \\
\hline Solving Complex Problems & Information Analysis, Consolidation and Repackaging \\
\hline
\end{tabular}

Deepening upon need a System Analyst needs they have to evaluate the code, and reviewing the scripts and similar systems. They have to deal with software analyst and network administrators.

\section{Network Administrator-}

The Position of a Network Administrator is similar to Systems Administrator in many contexts. The Network Administrator has to work several tasks related to the networks. Many of the tasks of Network Administrator match the job with the Information Scientists as well. The core job of the Network Administrator is included but not limited to the following-

- Monitoring Systems and Networks.

- Testing and further evaluation of the systems depending upon need. Implementation of the security-related programs of an organization is also a valuable task of a Network Administrator.

- Implementing and evaluating healthy Network Systems and Management for a more advanced network.

- Creation of intelligent and sophisticated Information Systems and Networks depending upon need [17], [29].

Moreover, as a Network Administrator, they have to deal with the policy making, implementation of an advanced network and better network governance. The Network Administrator also need to take care of the managerial aspects of network and security management. 


\section{Findings-}

- The task and required knowledge level of the Information Scientist need much wider than any information professionals mentioned.

- Information Scientists have to work as a technologist and there is a need to view or solve any problems with the managerial and scientific contexts.

- Information Scientist normally recruited in the universities in India whereas in most other countries also absorb in the companies and organizations for the information and technology management.

- Information Scientist is similar to the CIO in terms of knowledge level and periphery; where many of the work matches with Network Administrator, System Administrator.

\section{Suggestions-}

- Information Scientist needs to upgrade depending upon need from all the spectrum of knowledge like management, information studies, and mostly information and communication technologies.

- They may be getting in touch with the other related professionals and scientific associations and foundations for better and healthy job results.

- Information Scientist needs to keep more communication and coordination with others compare to other related and allied professionals.

- Information Scientist needs to oversee the latest trends in the profession and allied fields and thus he/she have to handle the scientists, journals etc.

\section{Conclusion-}

The Information Scientist is an academic and professional position but it depends on the job and place of the work. Normally in the universities, the Information Scientist has to do the professional jobs which include information management and information designing for the academician and researchers. Information Scientist also needs to take care of technology management. Hence Information Scientist has to fulfil the dual role as 'professional and academician'. In the organizations and companies, the Information Scientist only take care of the information analysis, information designing and whole information system designing and development depending upon need.

\section{References-}

[1] Abeysekera, I. and Guthrie, J. (2004). "How is intellectual capital being reported in a developing nation?", in Research in Accounting in Emerging Economies, Supplement 2: Accounting and Accountability in emerging and transition economies, Page 149-169.

[2] Agarwarl, Suren, (1989). "Development of Documentation in India: Social Science Information”, New Delhi, India: Concept Pub. Co. Page 331.

[3] Balwan Singh and Kapila, P.C. (2004). "Search Engines: Tools For Library" in Annals of Library And Information Studies, S1.3, 93-98.

[4] Bansal, Alka et.al (2005). "Securing the future of Information: Digitization and Preservation of Documents in eFormat" in DESIDOC Bulletin of Information Technology, 25(1), 19-26.

[5] Buckland, Michael K and Liu (1995). "History of Information Science" in Annual Review of Information Science and Technology, 30, 385-416.

[6] Wang, C., Wang, Q., Ren, K. and Lou, W. (2010). "Privacy-Preserving Public Auditing for Data Storage Security in Cloud Computing, Proceedings of IEEE-INFOCOM, March, 1-9.

[7] Garfield, E. (1985). Essays of an Information Scientist, Vol: 8, p. 444-459, 1985 Current Contents,\# 47, p. 3-18, November 25, 1985. Current Contents, 47, 3-18.

[8] Garfield, E. (2001). Recollections of Irving H. Sher 1924-1996: polymath/information scientist extraordinaire. Journal of the American Society for Information Science and Technology, 52(14), 1197-1202.

[9] Davenport, L., \& Cronin, B. (1989). What does hypertext offer the information scientist?. Journal of information science, 15(6), 369-372.

[10] Marco, G (1996). "Two false dogmas of Information Science" in New Library World, 97(11), 11-14.

[11] Mangla PB (2003). "Information Society, Information Systems And National Development: A Conceptual Approach." In Annals of Library and Information Studies 50(2), 91-98. 
[12] Chandrakant, N. et.al. (2011). "Maximizing Lifetime of Wireless Sensor Network by using energy efficient middleware service", in International Journal of Innovative Technology and Creative Engineering, 1, 20-24.

[13] Chandrakant, N. (2013). "Green Computing and Mobile Cloud Computing inspired Middleware for Next Generation" in International Journal of Advanced Research in Computer Science and Electronics Engineering, 2(7), $542-545$.

[14] Nithya Sankar and Rau, S. S. (2011). "Managing Emotions to Managing Human Capital", International Journal of Management (IJM), 2 (2), 176 - 181.

[15] Paul, P. K. (2012). Information Scientist: Roles and Values with special Reference to their Appropriate Academic Programme and its availability in India. International Journal of Information Dissemination and Technology,2(4), 245.

[16] Paul, P. K., Rajesh, R., Chaterjee, D., \& Ghose, M. K. (2013). Information scientist: Technological and managerial skill requirement in 21st century: An overview. Information Studies, 19(1), 29.

[17] Paul, P. K., (2013a). "Information Science and Technology [IST] and its comparision with Information Technology and Social Computing" in Abhinav National Journal of Science and Technology, 2 (3), 17-25.

[18] Paul, P. K., (2013b). "Service Science Nature in Information Science: Overview" in Abhinav National Journal of Commerce and Management, 4 (2), 176-181.

[19] Paul, P. K., S Govindarajan , Dipak Chaterjee , R Bhatnagar (2013). "Information Systems and Information Science: Overview emphasizing comparative study" in SIT Journal of Management, 3 (1), 336-341.

[20] Paul, P. K., (2013e). "Social Computing and Social Informatics: The stakeholders of Knowledge Society emphasizing similarities and dissimilarities at a glance" in Abhinav National Journal of Science and Technology, 2 (4), 25-32.

[21] Paul, P. K., D Chatterjee (2013). "Information Engineering [IE] and its overview with special reference to MTechInformation Engineering in Indian perspective" in The Sci-Tech International Journal of Engineering Sciences, 1 (1), 71-79.

[22] Bianchini, R. and R.Rajamony (2004). "Power and energy management for server systems" in IEEE Computer, 37 (2), 68-74.

[23] Sharmila, R. and Subramani, A. (2013). "Impact of Business Intelligence Tools in Executive Information Systems", in International Journal of Computer Engineering and Technology (IJCET), 4(1), 1-7.

[24] Renouf, A. (1993). What the linguist has to say to the information scientist.Journal of Document and Text Management, 1(2), 173-190.

[25] Raghvan, K.S (2007). "Education For The Information Management Profession: Challenge And Opportunities" in DESIDOC Bulletin of Information and Technology, 27(2), 21-26.

[26] Tague, J., \& Carroll, J. (1973). Opinion Paper. Information in an Informationless World or The Making of an Information Scientist. Journal of the American society for information science, 24(1), 40-44.

[27] Vickery, Brian C (1994) "Fifty Years of Information Progress: A Journal of Documentation Review" London, England: in ASLIB;. Page-243.

[28] W. Boyd Rayward, (1997). "The Origin of Information Science and the International Institute of Bibliography/ International Federation for Information and Documentation", in Journal of the American Society for Information Science, 48(4), 289-300.

[29] W. Kintsch (2003). "On the notion of theme and topic in psychological peocess models of text comprehension', in: W.v. Peer, Parsing for the theme. A computer based approach. Amsterdam, Philadelphia: John Benjamins Publishing, 158170. 